\title{
コンクリート用砕砂の粒度分布 の表示方法に関する検討
}

\section{STUDY ON EXPRESSION METHOD FOR GRADING OF CRUSHED SAND FOR CONCRETE}

阿部道彦— $* 1$

キーワード :

砕砂, 粒度, 表示方法, 三村式, 修正ロジン - ラムラー式

Keywords:

Crushed sand, Grading, Expression method, Mimura's equation, Modified Rosin-Rammler's equation

\section{Michihiko ABE_— $* 1$}

Grading of crushed sand is different from that of natural sand. In this report, in order to simplify the expression method of grading of crushed sand, modified Rosin-Rammler's equation was studied instead of Mimura's one with five experimental constants. It was found that the grading of crushed sand can be expressed with modified RosinRammler's equation using two experimental constants and introduction of fineness modulus to the equation was considered. Based on the existing data and the provided equation in this study, it is suggested that one of the stipulations on crushed sand of JIS A 5005 may be reconsidered.

\section{1. はじめに}

わが国は、以前良質な河川産骨材に恵まれていたが、地域により次 第に良質なものが採取されなくなり、細骨材は川砂から他の天然砂に 移行し、天然砂と砕砂の混合使用や最近では砕砂の単独での使用もみ られるようになってきている。砕砂が JIS A 5004 (コンクリート用砕 砂）注1)として規格化されたのは 1980 年であるが、すでにそれ以前か らレディーミクストコンクリート工場やコンクリート製品工場で砕 砂が使用されており 1)、ダムでは 1955 年竣工の上椎葉ダムをはじめ、 多くのダムに使用されてきている2)。

天然砂の粒度分布は、図 1 に例示 ${ }^{3)}$ するように一般に対数正規分布 に近い分布を示すため、その数学的な取扱いが容易であり、D. A. Abrams が 1918 年に提唱した粗粒率は粒度分布の平均值に相当する。 それに対し、岩石を破砕して製造する砕砂は、図 2 に例示 ${ }^{4}$ するよう にそれとはやや異なる下に凸の粒度分布を示し、筆者もそれを確認し ている ${ }^{5)}$ 。なお、図 1 および図 2 で用いた標準偏差 $\sigma$ は、文献 6) と同 様の方法で求めている。

砕砂の粒度分布を示す式として、三村らと山岡がそれぞれ式（以下、 三村式、山岡式という）を提示している7),8) が、それらは複雑な式の ため本稿では簡略化した式として Rosin-Rammler の式 9)を修正した 式（以下、修正 Rosin-Rammler 式という）について検討を行うこと とし、かつ、粗粒率を式に取り込むこととした。また、今回文献で調 べた砕砂の粒度分布の実態および修正 Rosin-Rammler 式に基づき、 連続するふるいの間にとどまるものの質量分率を $45 \%$ 未満とする JIS A 5005 （コンクリート用砕石及び砕砂）の規定（以下、45\%未満規定 という) の必要性を検討した。

\section{2. 検討の方法}

\section{1 砕砂の粒度分布を表示する既往の式}

前述したように砕砂の粒度分布を示寸式としては三村式と山岡式 がある。ここではまず両者の式を紹介し、次いで本検討で用いた修正 Rosin-Rammler 式について説明することとする。

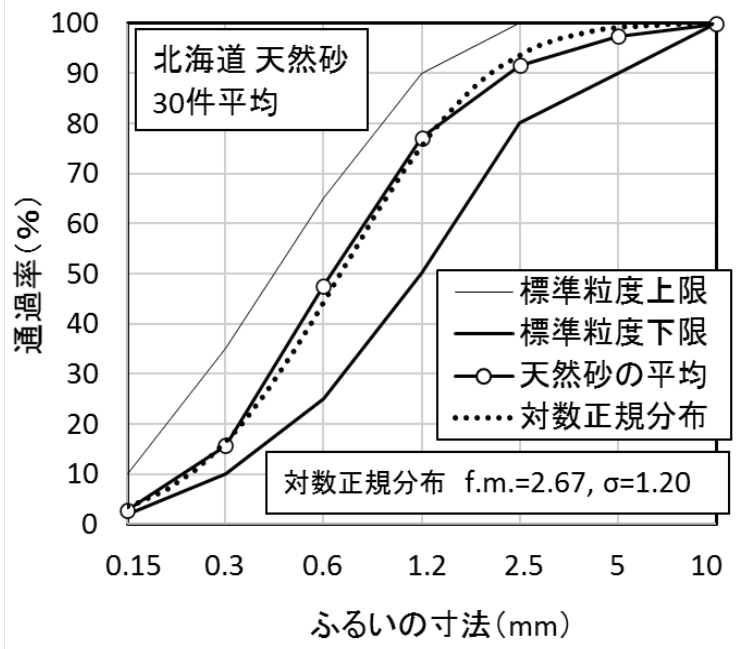

図 1 天然砂の粒度分布と対数正規分布への適合性

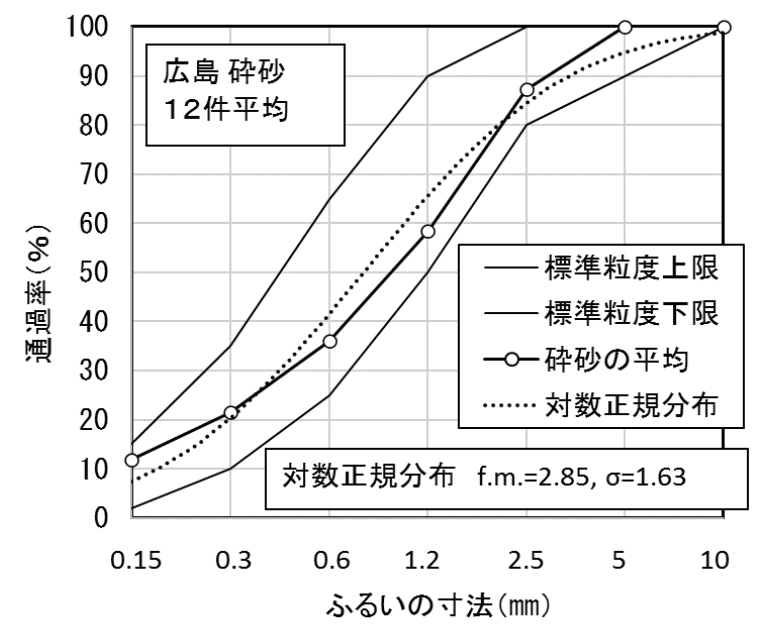

図 2 砕砂の粒度分布と対数正規分布への適合性 
(1) 三村式

ロッドミルを用いた実験に基づく三村式を式(1)に示す。この式は、 10 を底とし、べき指数に 4 次の多項式の逆数を含み、そのため実験定

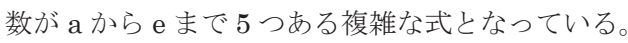

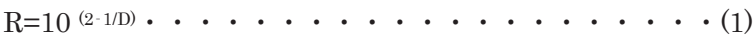

$\mathrm{R}$ : 累加残留率（\%）注 2)

$\mathrm{D}: \mathrm{a}+\mathrm{b}\left(\log \left(\mathrm{x} / \mathrm{x}_{0}\right)\right)+\mathrm{c}\left(\log \left(\mathrm{x}_{\mathrm{x}} \mathrm{x}_{0}\right)\right)^{2}+\mathrm{d}\left(\log \left(\mathrm{x} / \mathrm{x}_{0}\right)\right)^{3}+\mathrm{e}\left(\log \left(\mathrm{x}_{\mathrm{x}} / \mathrm{x}_{0}\right)\right)^{4}$ $\mathrm{x}$ ：ふるいの寸法注 2$)(\mathrm{mm})$

$\mathrm{x}_{0}$ : 砕砂の細かさを表す定数で、本稿では粒度曲線上に おける通過率 $50 \%$ のときのふるいの寸法の推定值 $\mathrm{P}_{50}(\mathrm{~mm})$ をいう。

（以下、 $50 \%$ 通過寸法または $\mathrm{P}_{50}$ と略記）

$\mathrm{a}, \mathrm{b}, \mathrm{c}, \mathrm{d}, \mathrm{e}$ : 実験定数 $(\mathrm{a}=3.215, \mathrm{~b}=-7.713$, $\mathrm{c}=8.622, \mathrm{~d}=-4.326, \mathrm{e}=0.504)$

\section{(2) 山岡式}

山岡は大野ダムにおける輝緑凝灰岩を用いたロッドミルによる実 験より、式(2)を提示している。この式は、べき指数の 4 次の多項式を 逆数としていない点が三村式と異なっている。また、 $\mathrm{x} / \mathrm{x}_{0}=1$ のときは $\mathrm{S}=50$ となることから、 $\mathrm{a}=\log 50=1.699$ としている。ただし、この式 は $1.2 \mathrm{~mm}$ から $5 \mathrm{~mm}$ までの通過率の適合性が三村式より良くないた め、本稿では検討の対象としないこととしている。

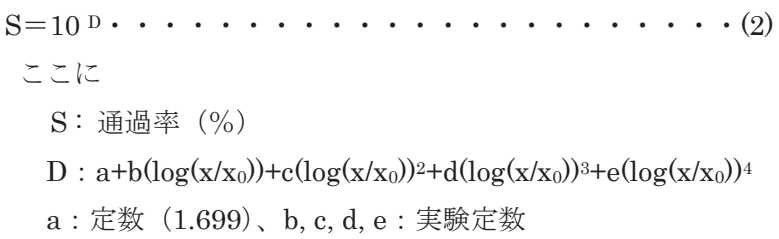

\section{2 本検討で用いた修正 Ros in-Rammler 式}

三村らは、論文の中でミル破砕物の粒度分布の関数の形として Rosin-Rammler の式が有名で、また、それよりさらに簡単な Bond の式もあるが、これらの式が適用できないことは、試験の結果から明 らかであるとしている。後者の式については一見して適用困難と思 われたが、前者については検討の余地があると考え、本稿では前者の 式について検討することとした。

Rosin-Rammler の式の表示方法はいくつか提案されているが、こ こでは三村式に準じて $\mathrm{x}_{0}$ を式に用いることとし、式(3)に示すように 元の式の 2 つの実験定数 $\mathrm{B} 、 \mathrm{C}$ に $\mathrm{A}$ を加えて 3 つの実験定数を設定し てこの式を修正 Rosin-Rammler 式（図中では R-R 式と略記）と呼ぶ こととした。そして、実験定数をソルバー解析で求めた。

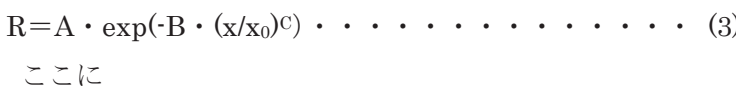

A は元の Rosin-Rammler の式では 100 としているが、対象とする
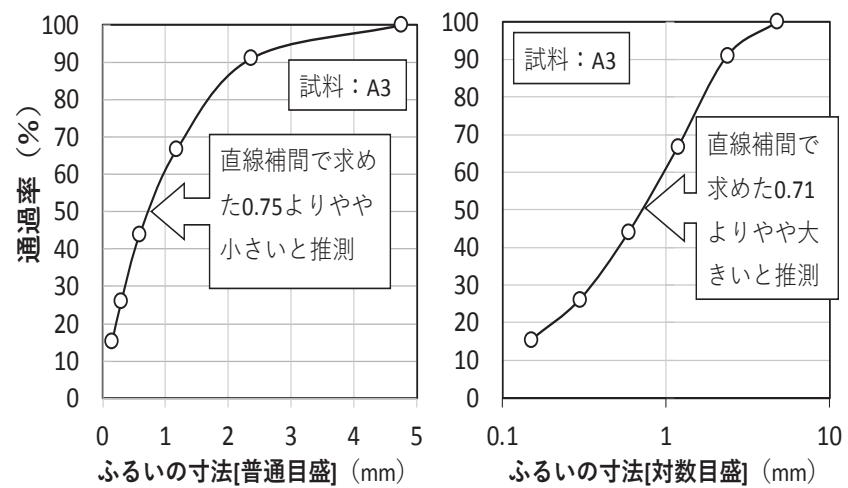

図 $3 \quad P_{50}$ を求めるときの目盛の相違の影響

表 1 三村式と本検討における $P_{50}$ の比較

\begin{tabular}{|c|c|c|c|c|c|c|}
\hline 試料 & \multicolumn{4}{|c|}{$50 \%$ 通過寸法 $P_{50}(\mathrm{~mm})$} & \multicolumn{2}{|c|}{ 残差平方和 } \\
\hline $\begin{array}{c}\text { の } \\
\text { 種類 }\end{array}$ & 三村 & $\begin{array}{l}\text { 普通 } \\
\text { 目盛 }\end{array}$ & $\begin{array}{l}\text { 対数 } \\
\text { 目盛 }\end{array}$ & $\begin{array}{l}\text { 左2 } \\
\text { の平均 }\end{array}$ & 三村式 & 本検討 \\
\hline A1 & 1.75 & 1.77 & 1.67 & 1.72 & 23.9 & 14.7 \\
\hline $\mathrm{A} 2$ & 1.25 & 1.24 & 1.22 & 1.23 & 11.2 & 2.9 \\
\hline A3 & 0.74 & 0.75 & 0.71 & 0.73 & 10.5 & 2.0 \\
\hline A4 & 0.52 & 0.51 & 0.49 & 0.50 & 5.9 & 5.6 \\
\hline A5 & 0.32 & 0.33 & 0.32 & 0.33 & 26.5 & 48.2 \\
\hline \multicolumn{5}{|c|}{ 和の平均 } & 15.6 & 14.7 \\
\hline
\end{tabular}

本検討で用いた三村式の係数は以下のとおり

$a=3.31, b=-7.37, c=7.31, d=-4.63, e=1.46$

粒度範囲（0.15mm 以上）における実験結果との適合性を考慮して本 稿では実験定数として設定したものである。

$\mathrm{x}_{0}$ については文献 7) および文献 8）には数值は記載されているが、 求め方はいずれの文献にも記載がない。このため、数值の記載のない 試料の $\mathrm{P}_{50}$ については、本稿では、横軸を普通目盛とした場合と対数 目盛とした場合について、それぞれ直線補間により $50 \%$ 通過寸法を求 め、両者の平均值（以下、精算值という）を用いることにした。その 理由は、図 3 に示すように、普通目盛で粒度曲線を表示すると、通過 率 $50 \%$ の前後ではやや上に凸の曲線となるため、直線補間すると $50 \%$ 通過寸法を実際の值より大きく推定することになるのに対して、対数 目盛で表示寸ると、これとは逆の結果になるためである。表 1 に三村 らの実験結果を用いて、 $\mathrm{P}_{50}$ について三村らの求めた值を用いた場合 と上述の本検討で求めた精算值を用いた場合の残差平方和を比較し て示しているが、試料 A5 以外は本検討のほうが小さくなり、残差平 方和の平均でもわずかに小さくなっている。

\section{3. 検討の結果}

\section{1 各種実験結果等への修正 Ros in-Rammler 式の適合性}

\section{（1）三村らの実験結果への適合性}

表 2 および図 4 は表 1 における 5 種類の試料を用いて三村式と修正 Rosin-Rammler 式の適合性を比較したもので、これらによると、修正 Rosin-Rammler 式を用いて実験定数を 3 個にした場合と 2 個にした 場合は、残差平方和の平均が三村式と同等かそれ以下の結果となった。 実験定数を 1 個にした場合は細粒の部分で $2 \sim 3 \%$ 実験値を下回った。 
表 2 三村式と修正 Rosin-Rammler 式の適合性

\begin{tabular}{c||c|c|c|c|c}
\hline 式の種類 & $\begin{array}{c}\text { 実験定数 } \\
\text { の数 }\end{array}$ & A & B & C & $\begin{array}{c}\text { 残差平方和 } \\
\text { の平均 }\end{array}$ \\
\hline \hline 三村式 & 5 & - & - & - & 15.6 \\
\hline \multirow{2}{*}{$\begin{array}{c}\text { 修正Rosin- } \\
\text { Rammler式 }\end{array}$} & 3 & 95.0 & 0.662 & 1.09 & 12.8 \\
\cline { 2 - 6 } & 2 & 98.0 & 0.704 & 1 & 15.8 \\
\hline
\end{tabular}

なお、三村らの文献では、縦軸は累加残留率で表示されているが、 煩雑さを避けるため、本稿では寸べて通過率で表示している。

\section{（2）上椎葉ダムに使用された砕砂への適合性}

図 5 は、上椎葉ダムにおけるロッドミルを用いた製砂の実績 10 試 料 ${ }^{10}$ について、上記と同様の検討を行ったもので、三村式では細粒部 分で実験值をやや上回った。このため、残差平方和が最小になるよう に実験定数を変更したところ、実験定数を 3 個にした場合の修正 Rosin-Rammler 式とほぼ同様の結果となった。ただし、実験定数を 変更した三村式では、図 5 から分るように、 $\mathrm{x} / \mathrm{P}_{50}$ が 5 を超えると通過 率が減少し、実験值から乘離していくため、注意が必要である。

\section{（3）奥只見ダムで行われた実験への適合性}

奥只見ダムの骨材生産計画のために花崗閃緑岩を用いて行われた ロッドミルによる実験 31 試料 ${ }^{11}$ について上記と同様の検討を行った (図 6 参照)。これによると、三村式は粗粒の部分でやや実験值より 小さくなっているものの良い適合性を示している。修正 Rosin-Rammler 式では、実験定数を適切に設定することにより粗粒 の部分でも適合性が良くなっており、残差平方和の平均は、三村式 38.5 に対し、修正 Rosin-Rammler 式では 24.6 となった。

\section{2 修正 Ros in-Rammler 式における各実験定数等の関係}

これまでの検討により、三村式と修正 Rosin-Rammler 式のいずれ においても、実験定数を適切に設定すれば、実験值をかなり良く推定 できることが確認された。修正 Rosin-Rammler 式は実験定数が 3 個 で三村式の 5 個に比べて少ないが、さらに簡略化することを検討した。 検討に用いた砕砂の試料の件数は、表 3 に示寸ように 1970 年以降の 152 件である。1970 年代の研究論文には粒度分布を示していたものが 多かったが、最近の研究論文等では、砕砂の粗粒率のみ示し、粒度分 布まで示したものが少ないため、デー夕はやや古い時期のものが多い。 なお、3. 4 までの検討では、実用性を考慮して粗粒率 4 以上のもの 3 件と極端なギャップグレードのもの 1 件を除いた 148 件の試料を対象 としている。

図 7 は、実験定数 $\mathrm{B}$ と A および $\mathrm{C}$ の関係、粗粒率および $0.15 \mathrm{~mm}$ 以下と実験定数 $\mathrm{B}$ および $\mathrm{C}$ の関係を示したものである。 $0.15 \mathrm{~mm}$ 以下 についても検討したのは、式(3)の関数の形から、0.15mm 以下が増加 すると、実験定数 $\mathrm{B}$ と $\mathrm{C}$ も大きくなると推測されたためである。これ らの関係のうち、実験定数 B と A の間には高い相関が認められ、 B を A で表示することが可能といえる。回帰式の係数 49.7 と 0.988 は、実

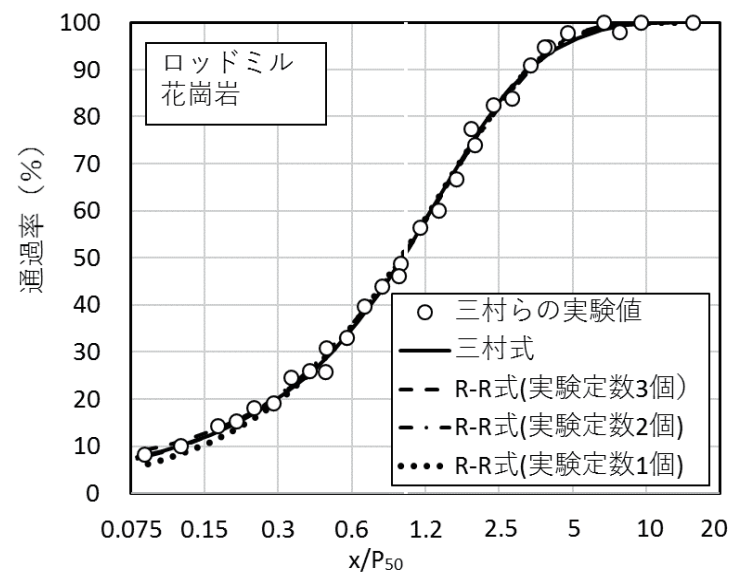

図 4 三村式と修正 Rosin-Rammler 式の比較

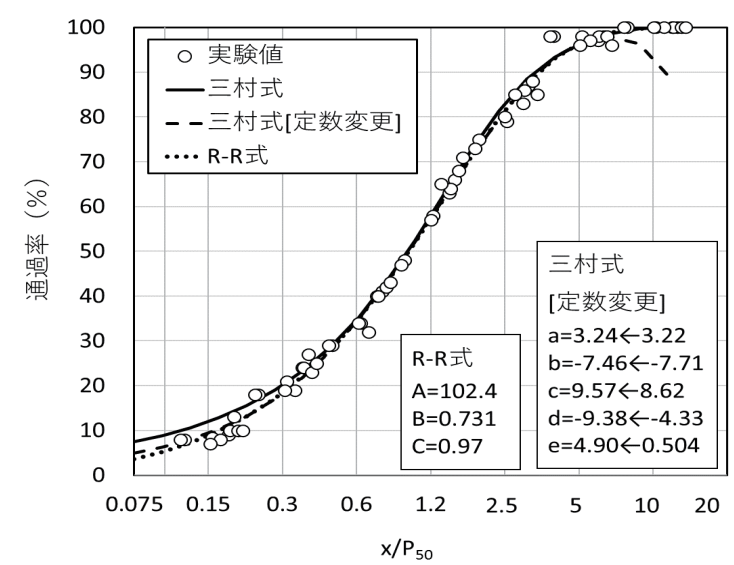

図 5 上椎葉ダムに使用された砕砂への適合性

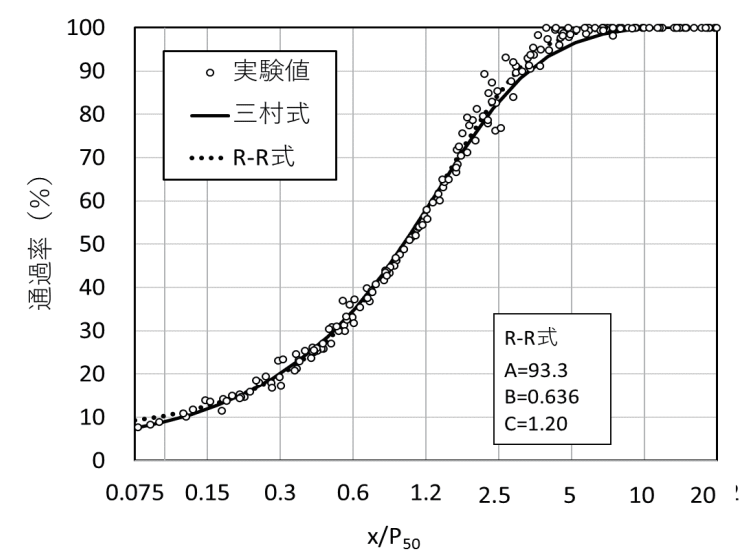

図 6 奥只見ダムの実験結果への適合性

表 3 実験定数の間の関係の検討に用いた試料

\begin{tabular}{l|l|r}
\hline \multicolumn{1}{c|}{ 掲 載 誌 } & \multicolumn{1}{c|}{ 期 間 } & 件数 \\
\hline \hline セメント技術年報 & $1970-1978$ & 12 \\
\hline セメント・コンクリート & $1973-1976$ & 6 \\
\hline セメント協会F-28 & 1976 & 12 \\
\hline 骨材資源 & $1971-2011$ & 39 \\
\hline 土木学会年次学術講演会講演概要集 & 1974 & 1 \\
\hline 日本建築学会大会梗概集・支部研究報告集 & $1976-1983$ & 30 \\
\hline 月刊生コン・コンクリートテクノ & $1991-2004$ & 19 \\
\hline コンクリートエ学論文集・年次論文集 & $1995-2012$ & 33 \\
\hline \multicolumn{2}{c|}{ 合 計 } & 152 \\
\hline \multicolumn{2}{|c|}{}
\end{tabular}



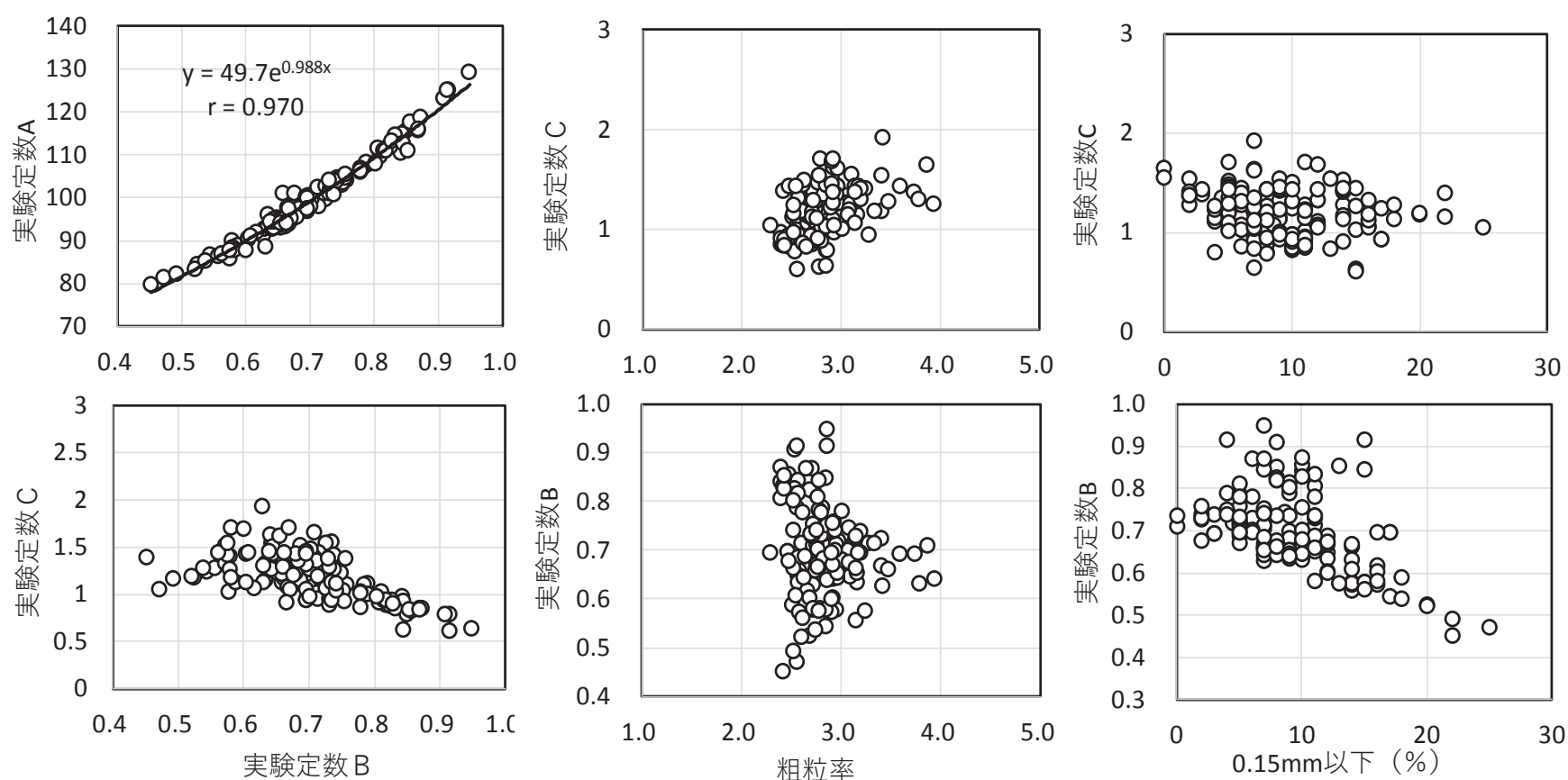

図 7 各実験定数、粗粒率および $0.15 \mathrm{~mm}$ 以下の関係

用上それぞれ 50 と 1.0 とみなしても差し支えないと考えられ、これ を式(3)に代入すると、累加残留率 R は次式となる。

$\mathrm{R}=50 \cdot \exp \left[\mathrm{B}\left\{1-\left(\mathrm{x} / \mathrm{x}_{0}\right) \mathrm{c}\right\}\right] \cdot \cdots \cdot(4)$

このほか、 $0.15 \mathrm{~mm}$ 以下と実験定数 B の間にもやや相関が認められ るが、JIS A 5005 の砕砂の粒度規定の上限である $15 \%$ 以下では相関 が明確でなく、これについては今後の課題としたい。

なお、全試料 148 件から求めた実験定数の平均值は、 $\mathrm{A}=99.7$ 、 $\mathrm{B}=0.700 、 \mathrm{C}=1.20$ となった。

\section{3 粗粒率の式への取込み}

コンクリートの調合計算を行うときには、細骨材の粗粒率の設定が 重要である。そしてそのためには、粗粒率 f.m. 注3) と $50 \%$ 通過寸法の 関係が明確になっていると便利である。図 8 は試料数(n)が 10 件以上 の文献を用いて両者の関係を示したもので、両者の間には高い相関が 認められた。文献ごとに求めた回帰式の係数を平均することも考えた が、表 4 に示すように、粗粒率のデータの範囲が文献によりかなり異 なるため、全データを一括して回帰式を求めることとした。求めた回 帰式から、式(3)の $\mathrm{x}_{0}$ には $0.0957 \exp (0.783 \times$ 粗粒率 $)$ を代入すればよ いこととなる（以下、 $\mathrm{P}_{50}$ の略算值という）。なお、得られた回帰式の 係数は、粗粒率の範囲の広い文献 11) と文献 7)の係数の平均 $(0.0957$, 0.786)にきわめて近い值となっている。

\section{4 修正 Rosin-Rammler 式の適合性の検討}

以上の検討により、砕砂の粒度を三村式の代わりに修正 Rosin-Rammler 式により表示できる可能性が示された。これまでの 検討はロッドミルを用いたダム用の砕砂に関する実験に基づいてい るが、ダム以外を対象に行われた表 3 に示寸実験に用いられた砕砂

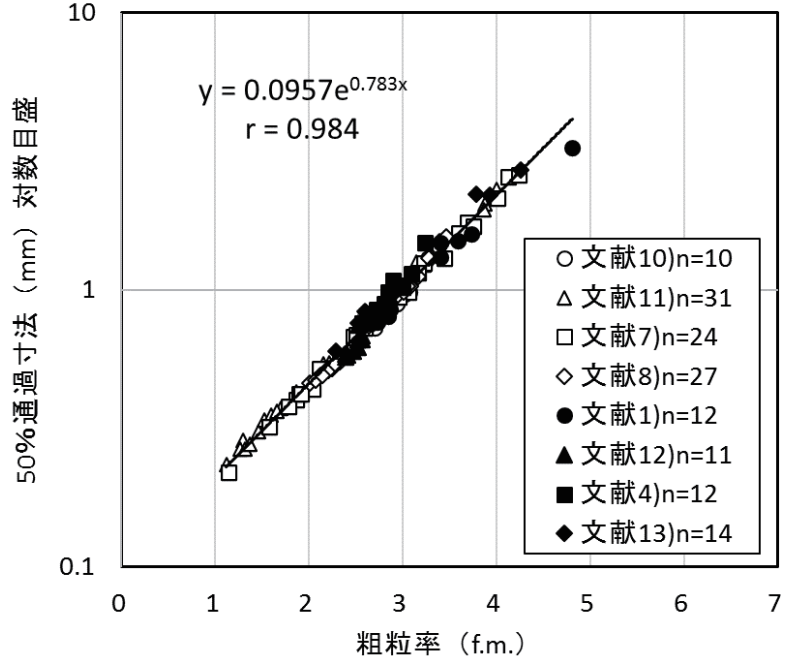

図 8 粗粒率と $50 \%$ 通過寸法の関係

表 $4 \quad P_{50}$ の算定に用いた粗粒率のデータの範囲

\begin{tabular}{|c|c|c|c|c|c|c|c|}
\hline \multirow{2}{*}{ 文献 } & \multirow{2}{*}{ 発表年 } & \multirow{2}{*}{$\begin{array}{c}\text { 試料数 } \\
\mathrm{n}\end{array}$} & \multicolumn{4}{|c|}{ 粗粒率 } & \multirow{2}{*}{$\begin{array}{c}\text { 粗粒率のxとした } \\
P_{50} \text { の回帰式 } \\
\end{array}$} \\
\hline & & & 最小 & 最大 & 範囲 & 平均 & \\
\hline 10 & 1954 & 10 & 2.68 & 3.27 & 0.59 & 2.92 & $0.0666 \exp (0.896 \mathrm{x})$ \\
\hline 11 & 1959 & 31 & 1.12 & 4.00 & 2. 88 & 2. 31 & $0.0987 \exp (0.782 x)$ \\
\hline 7 & 1959 & 24 & 1. 14 & 4.24 & 3. 10 & 2. 77 & $0.0927 \exp (0.790 x)$ \\
\hline 8 & 1963 & 27 & 2. 01 & 3.46 & 1.45 & 2. 64 & 0.0780 \\
\hline 1 & 1976 & 12 & 2. 56 & 4.81 & 2. 25 & 3. 20 & $0.1219 \exp (0.692 x)$ \\
\hline 12 & 1983 & 11 & 2. 39 & 2. 57 & 0.18 & 2. 50 & $0.0601 \exp (0.946 \mathrm{x})$ \\
\hline 4 & 1991 & 12 & 2. 57 & 3. 24 & 0.67 & 2. 85 & $0.0638 \exp (0.950 x)$ \\
\hline 13 & 2000 & 14 & 2. 29 & 4.26 & 1.97 & 2. 98 & $0.1023 \exp (0.782 x)$ \\
\hline \multicolumn{2}{|c|}{ 全体 } & 141 & 1.12 & 4.81 & 3. 69 & 2. 70 & $0.0957 \exp (0.783 x)$ \\
\hline
\end{tabular}



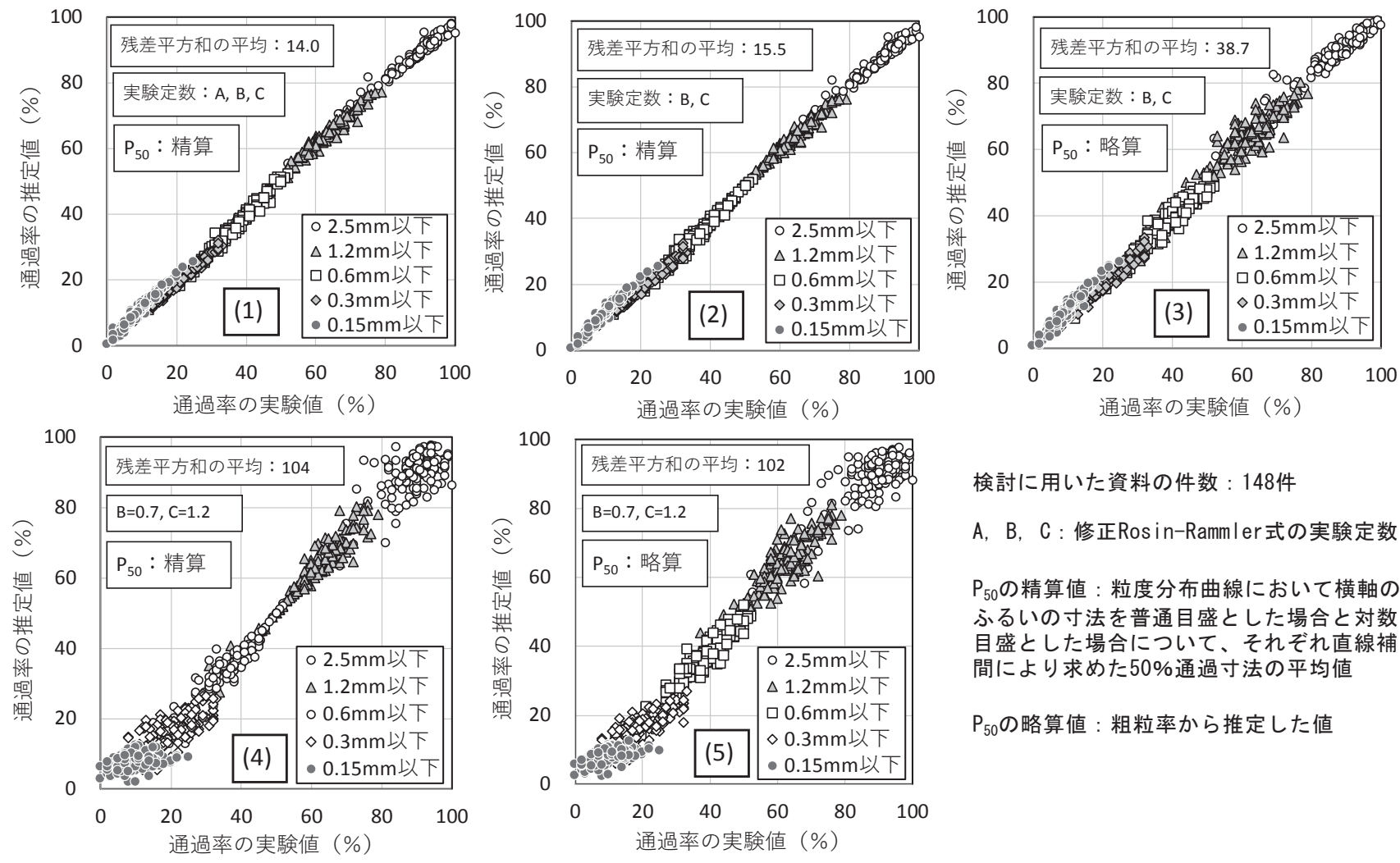

検討に用いた資料の件数：148件

A，B， C : 修正Ros in-Rammler式の実験定数

$\mathrm{P}_{50}$ の精算值 : 粒度分布曲線において横軸の ふるいの寸法を普通目盛とした場合と対数 目盛とした場合について、それぞれ直線補 間により求めた $50 \%$ 通過寸法の平均値

$P_{50}$ の略算值：粗粒率から推定した值

図 9 修正 Ros in-Rammler 式の適合性

152 件のうち 3.2 で述べた理由で 4 件を除いた 148 件の粒度について 修正 Rosin-Rammler 式の適合性を検討した。これらのデータには、 製砂機や製造条件の明示されていないものも多かったが、式の適合性 の全般的な傾向を把握するため、データを一括して扱うこととした。 なお、適合性については 148 件の各粒度の実験值と推定值の残差平方 和を求め、その平均で比較することとした。

図 9 に示寸 5 枚の図は、通過率の実験值と推定值の関係を様々な条 件で比較したものである。また、 $5 \mathrm{~mm}$ ふるいを通過するものはほと んど 100\%またはそれにきわめて近い值のため、2.5mm 以下のふるい の通過率について示している。

図 9(1) は、3 つの実験定数 A、B、C を用い、 $50 \%$ 通過寸法 $\mathrm{P}_{50}$ を 精算で求めたものである。これによると、修正 Rosin-Rammler 式に よりかなり精度よく砕砂の粒度が推定できることがわかる。

図 9 (2) は、実験定数をB と Cの二つにして、50\%通過寸法 $\mathrm{P}_{50}$ を精 算值とした場合である。これによると、実験定数を 3 個にした場合と 2 個にした場合でほとんど差のないことが分かった。

図 9(3) は、 $\mathrm{P}_{50}$ を精算值ではなく略算值を用いた場合である。精算 值を用いた場合に比べて、全体にやや精度が悪くなっており、特に通 過率 $50 \%$ 前後にその傾向が認められる。

図 9(4) は、実験定数 B と C をそれぞれ平均值である 0.7 と 1.2 に固 定し、 $\mathrm{P}_{50}$ を精算值とした場合である。通過率 $50 \%$ 前後での適合は良 いが、粗粒および細粒の部分で適合が悪くなっている。

図 9(5) は、 $P_{50}$ を略算值とした場合である。粗粒と細粒の部分では 図 9(4) とほとんど相違がないが、通過率 50\%付近ではばらつきが大 きくなっている。

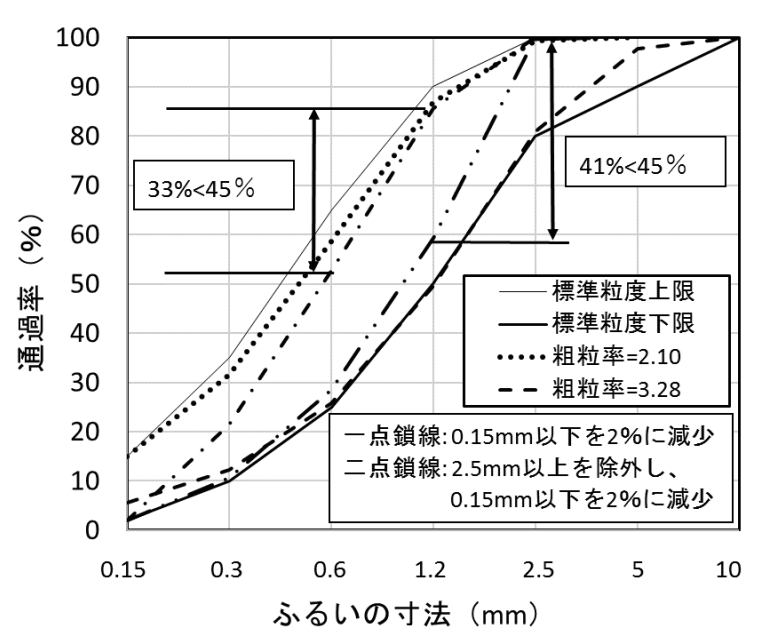

図 10 砕砂の $45 \%$ 未満規定に関する検討

\section{表 5 砕砂の $45 \%$ 未満規定の検討に用いた粒度}

\begin{tabular}{|c|c|c|c|c|c|c|c|c|c|}
\hline 粒度の種類 & |ふるいの寸法 $(\mathrm{mm})$ & 0.15 & 0.3 & 0.6 & 1.2 & 2.5 & 5 & 10 & 粗粒率 \\
\hline \multirow{2}{*}{$\begin{array}{c}\text { 標準粒度の } \\
\text { 上限近傍 }\end{array}$} & 通過率（\%） & 15 & 32 & 58 & 87 & 99 & 100 & 100 & 2.10 \\
\hline & 通過率の差(\%) & 17 & 26 & 29 & 12 & 1 & - & - & - \\
\hline \multirow{2}{*}{$\begin{array}{l}\text { 上記より0.15mm以 } \\
\text { 下を2\%に減少 }\end{array}$} & 通過率 (\%) & 2 & 21 & 53 & 86 & 100 & 100 & 100 & 2.38 \\
\hline & 通過率の差 & 19 & 32 & 33 & 14 & 0 & - & - & - \\
\hline \multirow{2}{*}{$\begin{array}{c}\text { 標準粒度の } \\
\text { 下限近傍 }\end{array}$} & 通過率（\%） & 5 & 12 & 26 & 50 & 81 & 98 & 100 & 3.28 \\
\hline & 通過率の差 $(\%)$ & 7 & 14 & 24 & 31 & 17 & 2 & - & - \\
\hline \multirow{2}{*}{$\begin{array}{l}\text { 上記より } 2.5 \mathrm{~mm} \text { 以上 } \\
\text { を除去し、0.15mm } \\
\text { 以下を } 2 \% \text { に減少 }\end{array}$} & 通過率（\%） & 2 & 11 & 28 & 59 & 100 & 100 & 100 & 3.00 \\
\hline & 通過率の差 & 9 & 17 & 31 & 41 & - & - & - & - \\
\hline
\end{tabular}


なお、図 9(4)で通過率 50\%のところの対応がきわめて良くなって いるのは、 $\mathrm{P}_{50}$ を略算值ではなく、精算值を用いているためで、式(4) および式(1)から分るように、 $\mathrm{x} / \mathrm{x}_{0}$ が 1 になると、通過率 $50 \%$ のとき の推定值が $50 \%$ となることによるものである。

\section{5 砕砂の $45 \%$ 未満規定に関する検討}

表 3 に示寸砕砂 152 件のうち、連続するふるいの間にとどまるもの の質量分率の差が $45 \%$ 以上のものは、標準粒度範囲を大きく外れる砕 石砂注 $\left.{ }^{4}\right) 1$ 件（60\%、粗粒率 4.41） と混合用の砕砂 1 件（84\%、粗粒 率 4.81）で、それ以外では混合用も含めて最大でも $40 \%$ であった。

また、JIS A 5005 に規定される砕砂の粒度範囲内の粒度で修正 Rosin-Rammler 式（B=0.7、 $\mathrm{C}=1.2 、 \mathrm{P}_{50}$ : 精算值）に適合する粒度を 求めると、図 10 および表 5 に示すように粗粒率 2.10 から 3.28 の粒度 となる。これらの粒度について $45 \%$ 未満規定に適合しないものはない ため、連続するふるいの間にとどまるものの質量分率の差が大きくな るように、粗粒率 2.10 のものについて $0.15 \mathrm{~mm}$ 以下を粒度範囲の規 定值の下限である $2 \%$ に減少した場合と、粗粒率 3.28 のもので $2.5 \mathrm{~mm}$ 以上を除去し、 $0.15 \mathrm{~mm}$ 以下を $2 \%$ に減少した場合について検討した。 その結果、前者の場合には $0.6 \mathrm{~mm}$ と $1.2 \mathrm{~mm}$ の間にとどまるものが $33 \%$ 、また、後者の場合でも $1.2 \mathrm{~mm}$ から $2.5 \mathrm{~mm}$ の間にとどまるもの が $41 \%$ となり、 $45 \%$ 未満規定を満足することとなった。このため、 45\%未満規定、寸なわち JIS A 5005 の、連続するふるいの間にとど まるものの質量分率の差を $45 \%$ 未満とする規定は、砕砂に関しては削 除も含めた再検討が必要と考えられる。この規定は ASTM C33（コン クリート用骨材の仕様）14)から引用されたもので、土木学会のコンク リート標準示方書には規定があるが、JIS A 5308 (レディーミクスト コンクリート）附属書 A（レディーミクストコンクリート用骨材）の 砂、JASS 5 の砂およびJIS の各種スラグ細骨材には規定がない。

なお、現行の細骨材の粒度の規定は、天然砂を前提として設定され ていると考えられるが、今後砕砂の使用が増加することを考えると、 たとえば $2.5 \mathrm{~mm}$ 通過率の緩和なども今後の検討課題と考えられる。

\section{4.まとめ}

コンクリート用砕砂の粒度分布の表示方法について三村式と修正 Rosin-Rammler 式を比較し、また、JIS A 5005 の砕砂の 45\%未満規 定について検討した結果は次のようにまとめられる。

（1）ロッドミルで製造した砕砂の粒度分布は、三村式では実験定数は 5 個であるが、修正 Rosin-Rammler 式を用いると、実験定数を 2 個とした場合でも残差平方和による比較では三村式とほぼ類似の 精度で表示できることが確認された。

（2）修正 Rosin-Rammler 式の実験定数 A は、実験定数 B を用いて表 示可能であるため、実用的には修正 Rosin-Rammler 式は、実験定 数 B と C で表示するのが妥当である。

（3） $50 \%$ 通過時のふるいの寸法 $\mathrm{P}_{50}$ は、粗粒率を用いて推定することが できるが、この場合、通過率 50\%付近の通過率の推定值は、やや ばらつく結果となった。

(4) JIS A 5005 に規定されている砕砂の粒度範囲内であれば、砕砂の 連続するふるいにとどまるものの質量分率の差を $45 \%$ 未満とする JIS A 5005 の規定は削除も含めて再検討される必要があると考え られる。

\section{注}

注 1）JIS A 5004 (コンクリート用砕砂）は、1993 年に JIS A 5005 （コンクリ 一ト用砕石）と統合され、JIS A 5005 （コンクリート用砕石及び䃏砂）と なった。

注 2）ここでは、JIS の表記ではなく、既往の論文等に使用されている慣用的 な表記を用いている。

\begin{tabular}{|c|c|}
\hline $\begin{array}{l}\text { 本稿で用いた } \\
\text { 慣用的表記 } \\
\end{array}$ & JISの表記 \\
\hline ふるいの寸法 & $\begin{array}{l}\text { ふるいの公称目開き [JIS Z 8801-1（試験用ふるいー第1部： } \\
\text { 金属製網ふるい)] } \\
\text { ふるいの呼び寸法 [JIS A } 1102 \text { (骨材のふるい分け試験）] }\end{array}$ \\
\hline 累加残留率 & $\begin{array}{l}\text { 各ふるいにとどまる質量分率 [JIS A 1102］ } \\
\text { 各ふるいにとどまるものの質量分率 [JIS A 5005（コンク } \\
\text { リート用砕石及び砕砂） }\end{array}$ \\
\hline 通過率 & $\begin{array}{l}\text { 各ふるいを通過する質量分率 [JIS A 1102］ } \\
\text { ふるいを通るものの質量分率［JIS A 5005］ }\end{array}$ \\
\hline
\end{tabular}

注 3）粗粒率の記号としては、f.m.のほか大文字の F.M.も用いられる。 注 4）砕石からふるい出したもので、文献では砕石砂と記載されている。

\section{参考文献}

1）セメント協会：コンクリート専門委員会報告 F-28 細骨材の品質調查報告, 1976.12

2）永倉正 : 砕砂の利用と問題点, セメント工業, No.89, pp.67-71, 1967

3）服部隆：骨材の試験と粗骨材の破砕試験方法, 日本建築学会論文報告集, 第 57 号, pp.25-28, 1957.7

4) 藤井隆：骨材需給の実態と品質的諸問題 IV. 月刊生コンクリート, Vol.10, No.11, pp.53-57, 1991.11

5）阿部道彦: 粗粒率と標準偏差による細骨材の粒度の表示, 国立研究開発法人 建築研究所 令和 2 年度建築研究発表・討論会（材料部門），（材） 15-1 4, 2020.5

6) F. S. Fulton : The Fineness Modulus and the Grading of Aggregates, Concrete \& Constructional Engineering, pp.313-315, 1956.3

7）三村通精、鈴木勇、上野勇、細谷浩正：ロッドミルによる製砂方法に関す る研究，土木学会論文集、第 65 号・別冊 3-2, pp.1-17, 1959.12

8）山岡一三 : 製砂並びにロッドミル製砂の特性粒度分布曲線についての研究、 発電水力, No.63, pp.20-34, 1963.3

9) Rosin, P. \& Rammler, E. : The Laws Governing the Fineness of Powdered Coal, The Institute of Fuel, Vol.7, No.31, pp.29-36, 1933.10

10）沢崎璇：ダム建設における製砂用ロッドミル，神戸製鋼，Vol.4, No.4, pp.196-201, 1954.10

11）日本建設機械化協会：骨材の生産, pp.231-241, 1959.2

12）実松誠，杉田英明，米村方聖：九州地域で製造されている砕砂の物性とそ れを使用したコンクリートの性状について, 日本建築学会九州支部研究報 告, No.27, pp.29-32, 1983.3

13）骨材資源 砕砂特集号, Vol.32, No.127, pp.199-282, 2000.12

14) ASTM C $33-52 \mathrm{~T}$ : Tentative Specifications for Concrete Aggregates, 1952 [2021 年 6 月 2 日原稿受理 2021 年 8 月 19 日採用決定 $]$ 